\title{
Influence of pH to Increase Grafting Degree into Fluoropolymers
}

\author{
Giovanni González-Pérez, Ademar Benevolo Lugao* \\ Intitute of Nuclear and Energetic Research IPEN-USP, São Paulo, Brazil \\ Email: *ablugao@ipen.br
}

How to cite this paper: González-Pérez, G. and Lugao, A.B. (2017) Influence of $\mathrm{pH}$ to Increase Grafting Degree into Fluoropolymers. Open Journal of Polymer Chemistry, 7, 43-56.

https://doi.org/10.4236/ojpchem.2017.73004

Received: June 22, 2017

Accepted: August 27, 2017

Published: August 30, 2017

Copyright $\odot 2017$ by authors and Scientific Research Publishing Inc. This work is licensed under the Creative Commons Attribution International License (CC BY 4.0).

http://creativecommons.org/licenses/by/4.0/

\begin{abstract}
Poly(ethylene-alt-tetra-fluoroethylene (ETFE) and poly(tetrafluoroethylene-cohexafluoropropylene) (FEP) were pre-irradiated under air using a $\mathrm{Co}^{60} \mathrm{gam}$ ma source to graft styrene at low $\mathrm{pH}$. Grafting copolymers were tuned by study of different parameters (monomer, reaction time, temperature, and $\mathrm{pH}$ with addition of sulfuric acid $\left.\left(\mathrm{H}_{2} \mathrm{SO}_{4}\right)\right)$. The maximum degree of grafting was $80 \%$ and $40 \%$ for ETFE and FEP respectively at dose $2 \mathrm{kGy}$. Influence of low $\mathrm{pH}$ in grafting degree by adding sulfuric acid was studied. Grafting degree was examined by infrared (FTIR-ATR), differential scanning calorimetry (DSC) and swelling behavior analysis after sulfonation process.
\end{abstract}

\section{Keywords}

ETFE and FEP, Grafting Copolymer, Enhanced at Low pH

\section{Introduction}

As is known, fluoropolymers are used in a great variety of applications due to excellent physicochemical properties: chemical and thermal stability, hydrophobic, low surface energy, and environment resistance. Fluoropolymers have been modified by etching method or by ionizing radiation technology. Radiation technology is used as a grafting method to modify surfaces of materials in several areas (biomaterials, protective materials, wastewater treatment, fuel cells, alkaline cells, etc.) [1]-[13]. It is known, that several authors have been applied fluoropolymers to study of proton exchange membranes for fuel cell technology [14]-[19]. Modification of FEP (poly(tetrafluoroethylene-co-hexafluoropropylene)) and ETFE (poly(ethylene-alt-tetrafluoroethylene)) by styrene grafting, have been a low cost alternative to NAFION in the fuel cell and storage cell researches. In order to improve styrene grafting onto fluoropolymers using electron been radiation, Scherer's group has been optimized and developed sulfo- 
nated membranes of $50 \mu \mathrm{m}$ [20] [21] [22] [23] at low dose. Other authors have been employed gamma radiation or electron beam to maximize graft styrene at $100 \mathrm{kGy}$ [24] [25] [26] [27]. Gamma radiation has the advantage that penetration is higher than energy electron beams. For some applications where is not only grafting on surface important but also into bulk, gamma radiation is a better alternative. In order to increase grafting degree, sulfuric acid was added to monomer-solution to promote grafting into fluoropolymers at low $\mathrm{pH}$. Different additives have been used to increase grafting degree onto polymer substrates as an attractive and economical option, because better grafting results at lower dose were obtained [28] [29] [30] [31] [32]. Radiation dose required to carry out a particular grafting degree could be decreased at low $\mathrm{pH}$ with addition of mineral acid. Copolymers, synthesized at low dose, have no significant changes in its physico-chemical properties respect to synthesized at high dose (high dose promote crosslinking or scission in dependence of polymer structure). Addition of sulfuric acid $\left(\mathrm{H}_{2} \mathrm{SO}_{4}\right)$ (low $\mathrm{pH}$ solutions) in some grafting systems (natural or synthetic polymer) could improve grafting degree at low dose [29]-[37]. In some grafting systems, there has been important to research the influence of low $\mathrm{pH}$ in the increase of grafting results, because at some concentrations of adding acid, there is no enhancing effect [38]. Acid enhancing effect in fluoropolymers has been little studied [39], although grafting styrene into fluoropolymers (FEP [poly(tetrafluoroethylene-co-hexafluoropropylene)] and ETFE [poly(ethylene-alt-tetra-fluoroethylene)]) has extensively used for fuel cells [14] [21] [22] [40]-[47].

Acid enhanced could be due to irradiation of the solvent increases hydrogen atom yield $(\mathrm{G}(\mathrm{H})$ ), low $\mathrm{pH}$ of grafting solutions and partitioning effect (partitioning effect consists in increase of monomer diffusion through substrate improving homogenous grafting). The hydrated electrons are scavenged by hydrogen ion $\left(\mathrm{H}^{+}\right)$and transformed to hydrogen radical at low $\mathrm{pH}\left(\mathrm{H}^{+}+e \rightarrow H^{\bullet}\right)$. In solutions at low $\mathrm{pH}$, radical yields are rather higher than in neutral or basic solutions. Formed hydrogen radicals are able to abstract hydrogen atoms from polymeric matrix and create additional sites for grafting initiation. Increasing of additional grafting sites and diffusion of more monomer onto substrate promote increase in the grafting degree at low dose.

To study the behavior of low $\mathrm{pH}$ in the grafting degree sulfuric acid $\left(\mathrm{H}_{2} \mathrm{SO}_{4}\right)$ as an additive was added. In comparison with other authors, we pretend to obtain grafting degree at low dose ( 0 to $5 \mathrm{kGy}$ ). In this work, influence of low $\mathrm{pH}$ in the creation of additional grafting sites or optimization of monomer diffusion through fluoropolymer (ETFE and FEP), was studied. Styrene grafting degree into FEP and ETFE by gamma radiation was examined by infrared (FTIR-ATR), differential scanning calorimetric analysis (DSC) and swelling analysis.

\section{Experimental}

\subsection{Materials}

Toluene, ethanol, from Labsynth, Sulfuric acid $\left(\mathrm{H}_{2} \mathrm{SO}_{4}\right)$ from Merck, and styrene 
from Huntsman Ltda were used as received. Fluoropolymers with thickness 125 $\mu \mathrm{m}$ (FEP and ETFE) were supplied by Goodfellow. UK.

\subsection{Preparation of Grafting Copolymers}

Fluoropolymers were cut into $5 \times 2.5 \mathrm{~cm}$ pieces, washed in isopropanol and then dried at $60^{\circ} \mathrm{C}$ under vacuum for $8 \mathrm{~h}$. Cleaned polymers were weighed and irradiated by $\mathrm{Co}^{60}$ gamma radiation source using pre-irradiation oxidative method at room temperature (dose rate $10 \mathrm{kGy} / \mathrm{h}$ ). Low $\mathrm{pH}$ was studied by addition of acid at different molar acid concentrations (from 0.05 to $1 \mathrm{M} \mathrm{H}_{2} \mathrm{SO}_{4}$ ) and acid percentage (from $1 \%$ to $10 \%$ ), in solutions of monomer/solvent. Pre-irradiated fluoropolymers was put in glass tube $(30 \mathrm{~mL})$ with monomer-acid-solvent solutions and sealed under a nitrogen atmosphere. Sealed glass tubes were placed in a thermostatic bath at different temperatures and reaction times. After completed the reaction time, the residual unreacted monomer and homopolymer were removed from by Soxhlet system in toluene for $12 \mathrm{~h}$. Then glass tubes with grafting copolymers and toluene were put in sonication bath for $6 \mathrm{~h}$, and finally dried at $60^{\circ} \mathrm{C}$ under vacuum. Grafting degree $(G D)$ was calculated using the following equation:

$$
G D=100 \times\left(\left(G_{w g}-G_{w 0}\right) / G_{w 0}\right)
$$

where $G_{w g}$ and $G_{w 0}$ are grafted and initial weights respectively.

\subsection{Characterization of Grafting Copolymers}

Copolymers were characterized by FTIR-ATR spectra using previously dried films (Nexus 6700 FTIR Thermo Scientific, Nicolet 6700 FTIR-MID) and differential scanning calorimetry (DSC) (822 Mettler-Toledo under nitrogen atmosphere at a heating rate of $10^{\circ} \mathrm{C} / \mathrm{min}$, in the temperature range of $24^{\circ} \mathrm{C}$ to $350^{\circ} \mathrm{C}$ ). Swelling degree was used to check modification of grafting copolymers after sulfonation process (grafted films were previously sulfonated with 2 vol.\% chlorosulfonic acid in dichloromethane at room temperature for $8 \mathrm{~h}$, washed with distillated water for $24 \mathrm{~h}$ and dried at $60^{\circ} \mathrm{C}$ ). Modified samples were immersed in distillated water for $24 \mathrm{~h}$, removed from the solvent at different time intervals, their surface blotted with a piece of paper, weighed and placed again in water at room temperature. Swelling degree was calculated gravimetrically as follows:

$$
S_{w} d=\left(W_{s f}-W_{0}\right) / W_{s f} \times 100
$$

where $W_{0}$ and $W_{S f}$ are dried and swollen weights of grafted copolymers, respectively.

\section{Results and Discussion}

\subsection{Grafting Degree}

Styrene grafting onto FEP and ETFE films was done using oxidative pre-irradiation method. Absorbed dose, temperature, monomer concentration, acid-enhancing and reaction time were studied by tuning grafting degree. Grafting degree was 
calculated with the Equation (1). Monomer concentration was adjusted to graft styrene onto ETFE (ETFE-g-St) at 20\%, 40\% 60\% and 80\% (V/V styrene/ethanol) without acid. $\mathrm{pH}$ of these solution was between 5 and 6 . Figure 1 shows an increase in grafting degree with increase of styrene concentration as expected. Grafting degree does not show significant changes at higher concentrations because of homopolymer formation predominates over grafted into fluoropolymer, and there is not apparently dependence of dose in the grafting degree.

Figure 2 shows grafting degree as a function of molar acid concentration $\mathrm{H}_{2} \mathrm{SO}_{4}$. Grafting of styrene onto ETFE (ETFE-g-St) and FEP (FEP-g-St) was calculated with the Equation (1). 10\% of different molar acid concentrations were added at solution styrene/ethanol $(40 / 50 \mathrm{~V} / \mathrm{V})$. Figure 2 shows an increase at $0.05 \mathrm{M}$ in grafting degree, after $0.05 \mathrm{M}$ grafting degree decreased and remained without appreciable changes until $0.8 \mathrm{M}$. Increase-decrease behavior could depend of diffusion of styrene into fluoropolymer backbone promoted by dissolution of $\mathrm{H}_{2} \mathrm{SO}_{4}$ in the bulk grafting solution and influence of $\mathrm{pH}$ due to at low $\mathrm{pH}$ radical yields are higher to react with monomer and fluoropolymer. Grafting degree after $1 \mathrm{M}$ decreased anew because of less monomer available close to active sites where grafting carried out and homopolymer inhibition. Buzanowski and coworkers probed that incorporation of strong acids retarded or reduced homopolymerization rates, which could permit diffusion of styrene trough matrix before homopolymerization [48]. Due to monomer diffusion by interaction acid-monomer-fluoropolymer at $0.05 \mathrm{M}$, grafting degree was more favorable than without acid or superior molar concentrations of $\mathrm{H}_{2} \mathrm{SO}_{4}$. Most active radical species might be formed at low $\mathrm{pH}$. Active radical species rapidly decompose and interact with monomer-solvent that promotes a lot of free radicals to enhance grafting degree.

Figure 3 shows grafting degree as a function of different percentage of added acid. Grafting process took place at $2 \mathrm{kGy}$ using $\mathrm{H}_{2} \mathrm{SO}_{4} 0.05 \mathrm{M}, 70^{\circ} \mathrm{C}$ reaction

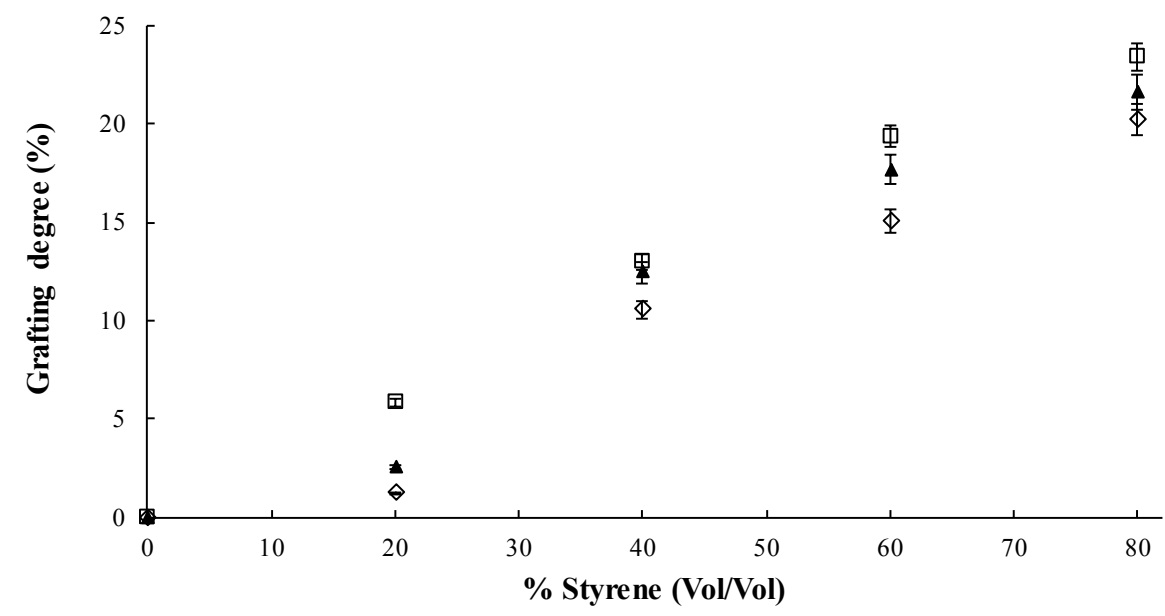

Figure 1. Grafting degree for ETFE as a function of the monomer concentration in ethanol at different dose, reaction temperature $60^{\circ} \mathrm{C}$ and reaction time $12 \mathrm{~h}$. $\bullet$ ) $\left.2 \mathrm{kGy}, \boldsymbol{\Delta}\right) 5$ $\mathrm{kGy}$ and $\mathbf{\square} 10 \mathrm{kGy}$. 


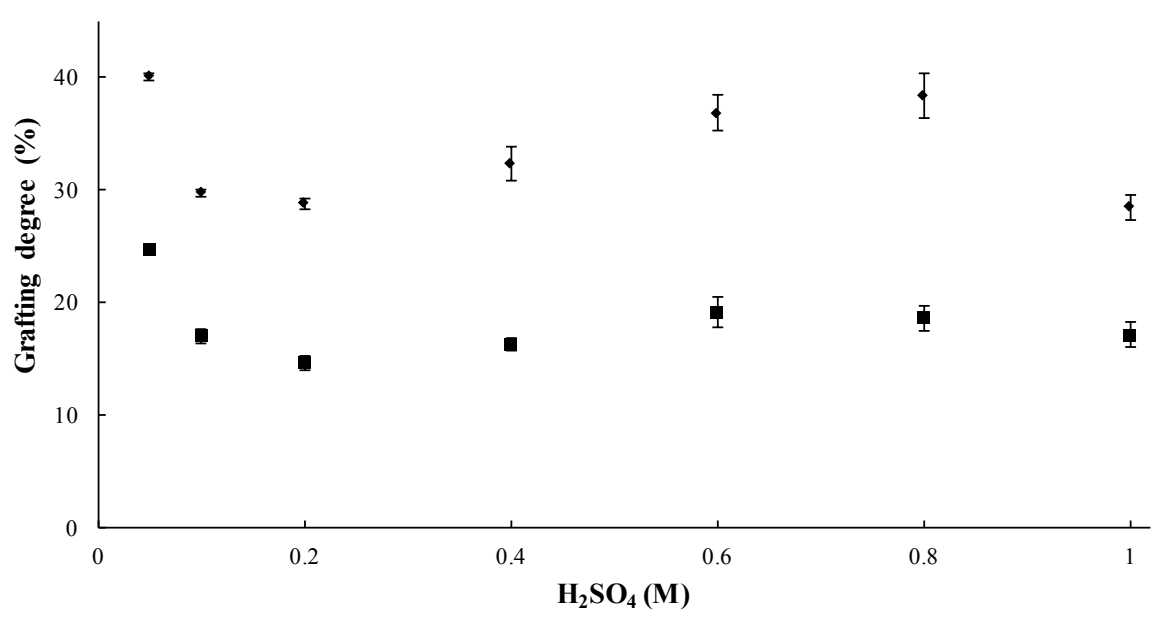

Figure 2. Grafting degree as a function of molar acid concentration $10 \%$ added in solution styrene/ethanol (40/50) at $2 \mathrm{kGy}$, reaction temperature $70^{\circ} \mathrm{C}$ and reaction time $24 \mathrm{~h}$.

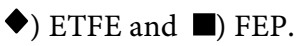

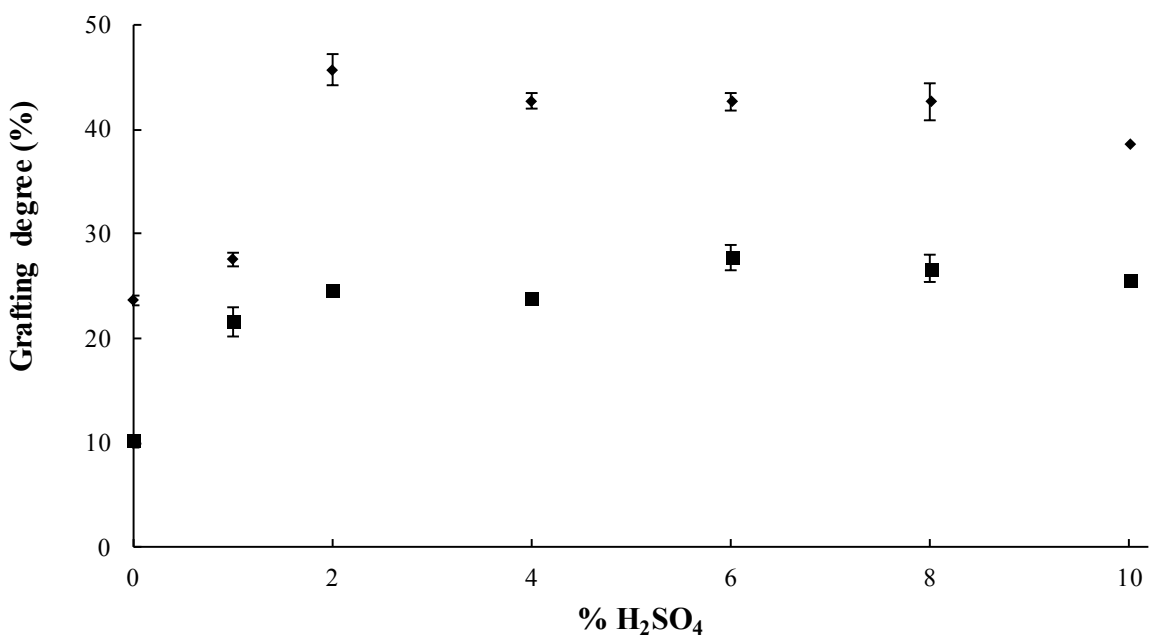

Figure 3. Grafting degree as a function of acid percentage added. Monomer concentration remained at $40 \%$ in ethanol, $\mathrm{H}_{2} \mathrm{SO}_{4} 0.05 \mathrm{M}$, dose $2 \mathrm{kGy}$, reaction temperature $70^{\circ} \mathrm{C}$ and reaction time $24 \mathrm{~h} \diamond$ ) ETFE and $\boldsymbol{\square}$ )FEP.

temperature for $24 \mathrm{~h}$ in thermostatic bath. For both grafting systems with ETFE and FEP, were presented maximum grafting degree at $2 \%$ of added acid $(\mathrm{pH}$ 3.3). Higher acid percentage $(1<\mathrm{pH}<4)$ could reduce homopolymerization and $\mathrm{pH}>4$ could increase competition with generated stable radicals and contribute to decrease of grafting degree. In the case of ETFE, is possible to generate more active sites available to grafting due to chemical structure and interaction of $\mathrm{C}-\mathrm{C}, \mathrm{C}-\mathrm{H}$ and $\mathrm{C}-\mathrm{F}$ bonds during gamma irradiation. In the case of FEP, C-C and $\mathrm{C}-\mathrm{F}$ are more difficult to produce radicals available for grafting.

Figure 4 shows grafting degree as a function of $\mathrm{pH}$. Grafting reaction was carried out at constant reaction time $(24 \mathrm{~h})$, temperature $70^{\circ} \mathrm{C}$, dose $(2 \mathrm{kGy})$ and concentration (40/60 styrene/ethanol). $\mathrm{pH}$ was changed from 1 to 5 with incorporation of sulfuric acid $0.05 \mathrm{M}$. Grafting degree showed an increase with 


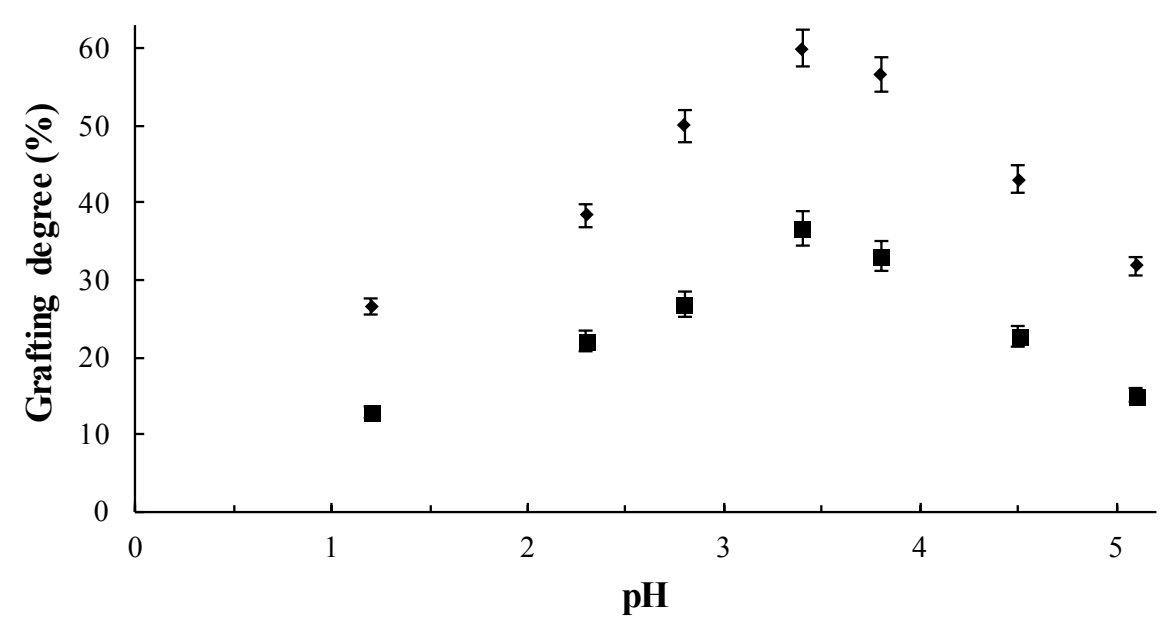

Figure 4. Grafting degree as a function of $\mathrm{pH}$. Monomer concentration remained at $40 \%$ in ethanol, dose $2 \mathrm{kGy}$, reaction time $24 \mathrm{~h}$, reaction temperature $70^{\circ} \mathrm{C}$ and $\mathrm{pH}$ was changed with $\mathrm{H}_{2} \mathrm{SO}_{4} 0.05 \mathrm{M}$. $\diamond$ ) ETFE and $\mathbf{\square}$ )FEP.

increases $\mathrm{pH}$ of solutions until $\mathrm{pH}>3$, where grafting degree decreases again. Both fluoropolymers had similar behavior in $\mathrm{pH}$ range studied. Not all $\mathrm{pH}$ have an enhanced effect in the grafting degree due to at low $\mathrm{pH}<1$ homopolymerization could be retarded and $\mathrm{pH}>4$ could occur first homopolymerization over grafting.

Figure 5 shows a grafting degree as a function of temperature. Grafting degree increased with increase of temperature due to activation of radicals. During grafting process, hydroperoxides are more active than peroxides with increasing temperature, which causes its decomposition and reaction with available monomer [49]. An increase in temperature promoted monomer diffusion into fluoropolymer increasing grafting degree. Differences in chemical structure between ETFE and FEP promoted higher radical formation in ETFE due to bond $\mathrm{C}-\mathrm{H}$ is easier to break than $\mathrm{C}-\mathrm{C}$ and $\mathrm{C}-\mathrm{F}$ during irradiation (Scheme 1). The radical formation in FEP is due to bond break $\mathrm{C}-\mathrm{C}$ or $\mathrm{C}-\mathrm{F}$, but is more probably that bond break $\mathrm{C}-\mathrm{C}$ occurs because of bond in $\mathrm{C}-\mathrm{F}$ is stronger than $\mathrm{C}-\mathrm{C}[50]$.

Figure 6 showed grafting degree as a function of reaction time. Grafting degree increase with reaction time as expected. Both grafting systems (FEP-g-St and ETFE-g-St) have not significant changes after $15 \mathrm{~h}$.

\subsection{FTIR-ATR Characterization}

Figure 7 shows FTIR spectra of fluoropolymers unmodified and modified with styrene. For ETFE, symmetric and asymmetric vibrations $\mathrm{CH}_{2}$ are at $2850-2920$ $\mathrm{cm}^{-1}$ respectively. At $1460 \mathrm{~cm}^{-1}$ and $1490 \mathrm{~cm}^{-1}$ represent C-H and C-F-C deformation respectively. $3100-3000 \mathrm{~cm}^{-1}$ can be assigned to stretching vibrations of the $\mathrm{C}-\mathrm{H}$ of aromatic ring. $2850 \mathrm{~cm}^{-1}$ is asymmetric stretching of $\mathrm{CH}_{2}$ of grafting styrene. At $1625 \mathrm{~cm}^{-1}$ corresponds to aromatic $\mathrm{C}=\mathrm{C}$ bonds stretching vibrations. The bands at $1670-1950 \mathrm{~cm}^{-1}$ are attributed to harmonic bands $\mathrm{C}-\mathrm{H}$ of the aromatic ring out of plane deformation. For FEP spectrum the bands are observed 


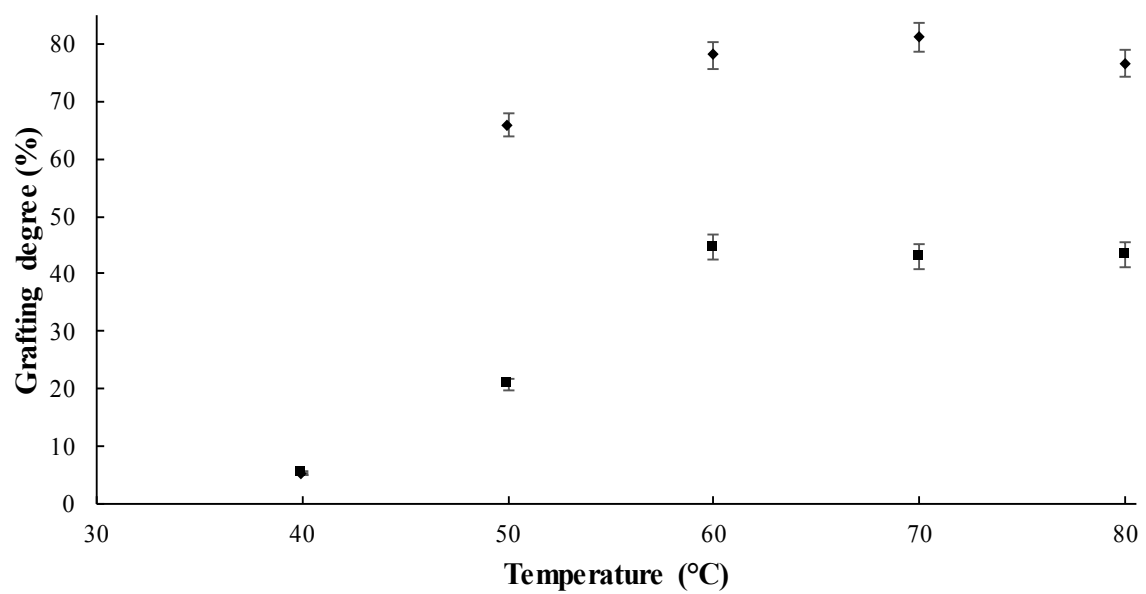

Figure 5. Grafting degree as a function of temperature. Dose $2 \mathrm{kGy}$, reaction time $24 \mathrm{~h}$, $\mathrm{pH} \sim 3.5$ and concentration (40/60 ethanol/styrene $\mathbf{0})$ FEP grafted with styrene and $\diamond$ ) ETFE grafted with styrene.



FEP Radicals<smiles></smiles>

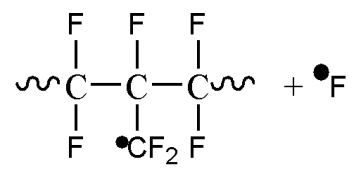<smiles>CC(C)C(C)C(C)(C)C(C)([13CH])C(F)(F)C(F)(F)C(C)(C)C</smiles>



ETFE Radicals<smiles>CC(F)(F)C(C)(F)F</smiles><smiles>CCCC</smiles>

Scheme 1. Radiation effects in ETFE and FEP.

the same than ETFE spectrum, but the Figure 6 shows the difference between unmodified FEP and modified with styrene. 


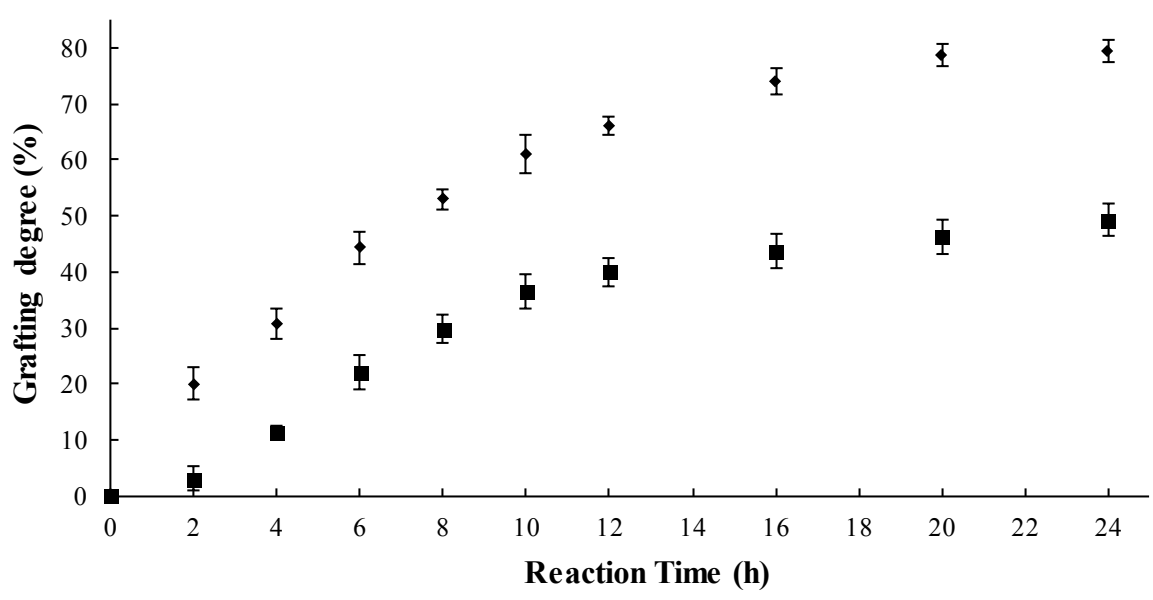

Figure 6. Grafting degree as function of reaction time, at constant temperature $\left(60^{\circ} \mathrm{C}\right)$, styrene concentration 60/40 (V/V) in ethanol, $\mathrm{pH} \sim 3.5$ and dose $2 \mathrm{kGy}$. $\square$ ) FEP grafted with styrene and $\bullet$ ) ETFE grafted with styrene.

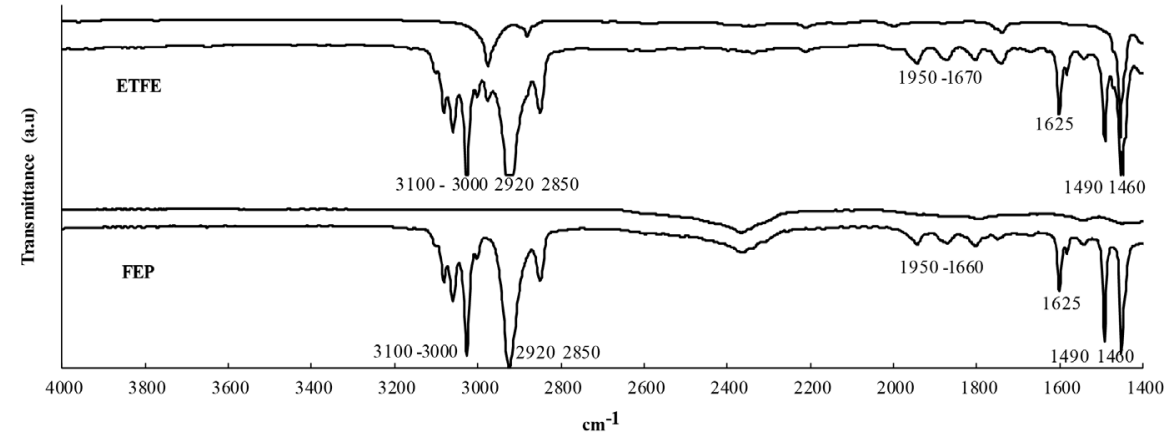

Figure 7. IR spectra of unmodified and modified ETFE and FEP with styrene.

\subsection{DSC Characterization}

Figure 8 shows DSC thermograms of initial fluoropolymer (FEP and ETFE) and grafting with styrene. DSC analysis was useful to find thermal transition temperatures and checked final grafting onto fluoropolymers. Membranes modified with styrene exhibited an apparently glass transition temperature $\left(\mathrm{T}_{\mathrm{g}}\right)$ at $87^{\circ} \mathrm{C}$ and $100^{\circ} \mathrm{C}$ for ETFE and FEP system respectively. $\mathrm{T}_{\mathrm{g}}$ and melting point temperature $\left(\mathrm{T}_{\mathrm{m}}\right)$ of polystyrene has been reported at $\sim 100^{\circ} \mathrm{C}$ and $240^{\circ} \mathrm{C}$ respectively [51] [52]. $\mathrm{T}_{\mathrm{m}}$ of grafting systems with styrene did not show an evident variation respect to initial fluoropolymers. This temperature variation was due to grafting process (radiation, reaction temperature, styrene diffusion). Thermogram could be an evidence of the grafting copolymer and confirm infrared analysis.

\subsection{Swelling Analysis}

After sulfonation of grafting fluoropolymers with styrene, swelling degree was studied by immersion of copolymers in distilled water as a function of time and grafting degree (Figure 9(a) and Figure 9(b)). Figure 9(a) shows that swelling degree has not significant variations up to $12 \mathrm{~h}$. Figure 9 (b) shows that swelling 


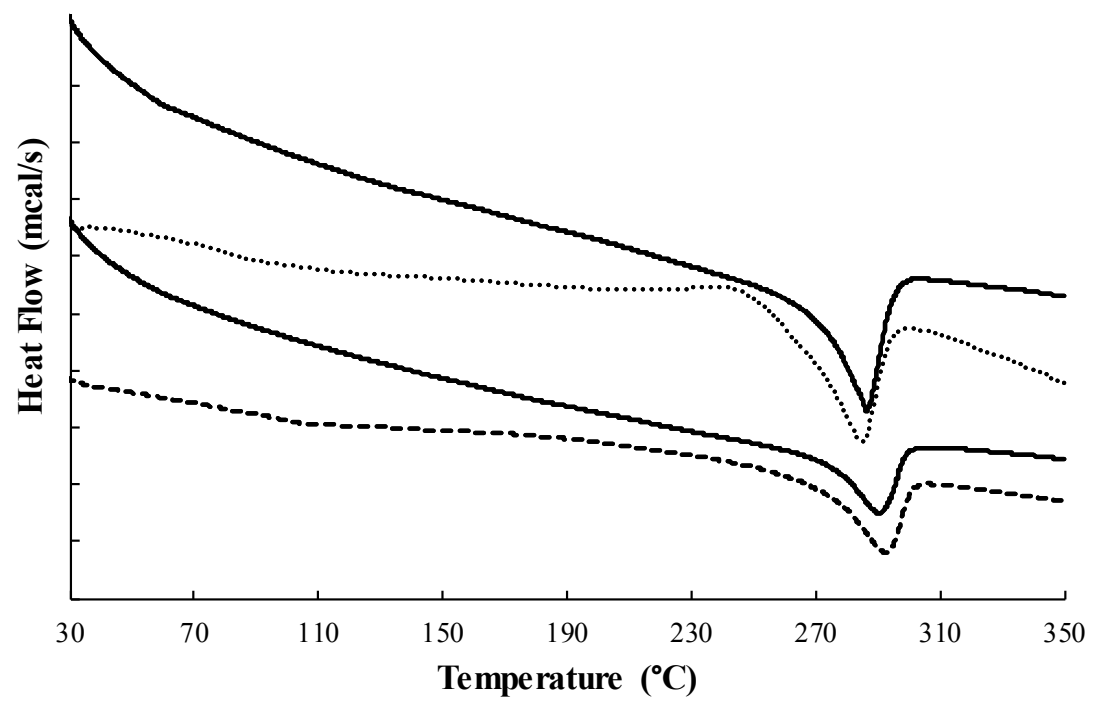

Figure 8. DSC thermograms of unmodified and modified fluoropolymers with styrene. ETFE-g-St and FEP-g-St.

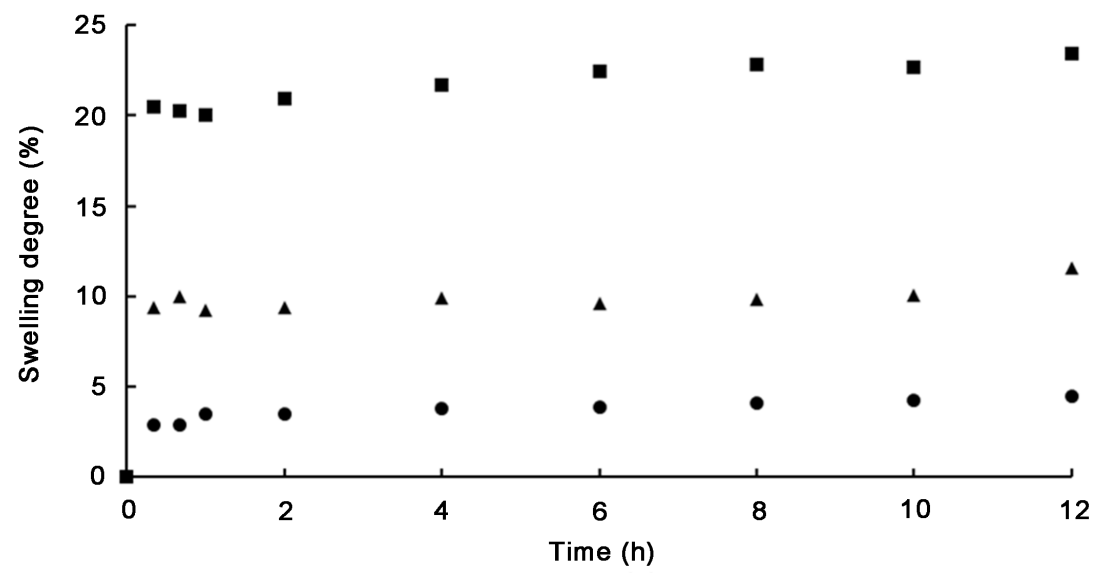

(a)



(b)

Figure 9. (a) Swelling degree as a function of time immersion in water. Sulfonated ETFE-g-St at different grafting degree: $), 10 \% \boldsymbol{\Delta}$ ) $22 \%$ and $\square) 38 \%$; (b) Swelling degree as a function of grafting degree for ETFE-g-St. 
degree increases with increase of grafting degree as expected after sulfonation process. Swelling degree remains constant after several cycles (drying at $60^{\circ} \mathrm{C}$ for $48 \mathrm{~h}$ and anew immersion in distilled water several times).

\section{Conclusions}

Grafting of styrene onto FEP and ETFE by pre-irradiation method in air was done and increased by tuning of $\mathrm{pH}$ with addition of $\mathrm{H}_{2} \mathrm{SO}_{4}$. The grafting of styrene onto FEP and ETFE was increased by optimization of monomer concentration, reaction time, reaction temperature and dose at $2 \mathrm{kGy}$ using gamma radiation. The best grafting degree of styrene onto FEP and ETFE was found $~ 40 \%$ and $80 \%$ respectively. Optimal conditions were styrene/ethanol concentration $60 / 40(\mathrm{~V} / \mathrm{V})$, reaction temperature of $60^{\circ} \mathrm{C}$ and reaction time of $15 \mathrm{~h}$. Grafting degree was optimized at $\mathrm{pH} 3.5$, where the most active radical species might be formed to graft enhancing into fluoropolymers, increasing reliability and application of these grafting films. FTIR-ATR confirmed grafting process onto fluoropolymers due to new band associated to grafting styrene and not only a presence of styrene. DSC technique confirmed the modification with styrene due to variation of thermal behavior of unmodified and modified copolymers with styrene. Different swelling degree of modified fluoropolymers reported in this work, confirmed the presence of grafting styrene. Grafting films with styrene were produced several times to confirm its reproducibility. Different grafting degrees for both systems could be employed in several applications as hydrogen membrane cells, encapsulation in solar cells devices or alkaline cells; in the case of alkaline developments, our group will use our modified fluoropolymers to research it in future.

\section{Acknowledgements}

The authors wish to express their thanks to Paulo de Souza Santos from CTR-IPEN-USP, for technical assistance in the irradiation, and FAPESP-2013/13144-0 for economic support.

\section{References}

[1] Stannett, V.T. (1990) Radiation Grafting State of the Art. Radiation Physics and Chemistry, 35, 82-87. https://doi.org/10.1016/1359-0197(90)90062-M

[2] Dondi, D., Buttafava, A., Faucitano, A., Arimondi, M., Ballabio, O. and Caracino, P.(2009) Post Irradiation Grafting of Styrene onto Polyethylene. Radiation Physics and Chemistry, 78, 521-524. https://doi.org/10.1016/j.radphyschem.2009.03.038

[3] Estrada-Villegas, G.M. and Bucio, E. (2012) Temperature and pH-Responsive Behavior of a Novel Copolymer of (PP-g-DMAEMA)-g-AAc. Journal of Radioanalytical and Nuclear Chemistry, 292, 1-6. https://doi.org/10.1007/s10967-011-1603-z

[4] Misra, S.K., Bhardwaj, Y.K. and Gandhi, P.M. (2013) Feasibility of the Recovery of Uranium from Alkaline Waste by Amidoximated Grafted Polypropylene Polymer Matrix. Journal of Radioanalytical and Nuclear Chemistry, 295, 471-475. https://doi.org/10.1007/s10967-012-1798-7 
[5] Kavaklı, P.A., Kavaklı, C., Seko, N., Tamada, M. and Güven, O. (2016) Radiation Induced Emulsion Graft Polymerization of 4-Vinylpyridine onto PE/PP Nonwoven Fabric for As (V) Adsorption. Radiation Physics and Chemistry, 127, 13-20. https://doi.org/10.1016/j.radphyschem.2016.05.020

[6] Kornacka, E.M., Przybytniak, G., Fuks, L., Walo, M. and Łyczko, K. (2014) Functionalization of Polymer Surfaces by Radiation-Induced Grafting for Separation of Heavy Metal Ions. Radiation Physics and Chemistry, 94, 115-118.

https://doi.org/10.1016/j.radphyschem.2013.05.047

[7] Iwanade, A., Kasai, N., Hoshina, H., Ueki, Y., Saiki, S. and Seko, N. (2012) Hybrid Grafted Ion Exchanger for Decontamination of Radioactive Cesium in Fukushima Prefecture and Other Contaminated Areas. Journal of Radioanalytical and Nuclear Chemistry, 293, 703-709. https://doi.org/10.1007/s10967-012-1721-2

[8] Sithambaranathan, P., Nasef, M.M. and Ahmad, A. (2015) Kinetic Behavior of Graft Copolymerization of Nitrogenous Heterocyclic Monomer onto EB-Irradiated ETFE Films. Journal of Radioanalytical and Nuclear Chemistry, 304, 1225-1234. https://doi.org/10.1007/s10967-015-3927-6

[9] El-Fadl. F.I.A. (2014) Radiation Grafting of Ionically Crosslinked Alginate/Chitosan Beads with Acrylic Acid for Lead Sorption. Journal of Radioanalytical and Nuclear Chemistry, 301, 529-535. https://doi.org/10.1007/s10967-014-3149-3

[10] Aggour, Y.A., Al-Shihri, A.S. and Bazzet, M.R. (2013) Chemical Modification of Scraped Tires through Grafting with 2-Acrylamido-2-Methylpropansulfonic Acid. Open Journal of Polymer Chemistry, 3, 48-53. https://doi.org/10.4236/ojpchem.2013.33010

[11] Barakat, M.F., El-Salmawy, K.M. and Zahran, A.H. (2016) Radiation Induced Grafting of Acrylic Acidonto Viscose Rayon Fabrics and Its After-Effects. Open Journal of Polymer Chemistry, 6, 27-42. https://doi.org/10.4236/ojpchem.2016.63004

[12] Kook, J.W., Lee, J.Y., Hwang, K.S., Park, I., Kim, J.H. and Lee, J.Y. (2016) Synthesis and Characterization of Poly(Methyl Methacrylate)/Polyethylenimine Grafting Core-Shell Nanoparticles for $\mathrm{CO}_{2}$ Adsorption using Soap-Free Emulsion Copolymerization. Advances in Materials Physics and Chemistry, 6, 220-229. https://doi.org/10.4236/ampc.2016.67022

[13] Barakat, M., Barakat, B.F.A., El-Salmawy, K.M. and Zahran, A.H.H. (2017) Radiation Induced Grafting of Viscose Rayon Fabrics with Some Acrylic Acid Derivatives and Styrene. Open Journal of Polymer Chemistry, 7, 1-18. https://doi.org/10.4236/ojpchem.2017.71001

[14] Smith, B., Sridhar, S. and Khan, A.A. (2005) Solid Polymer Electrolyte Membranes for Fuel Cells a Review. Journal of Membrane Science, 259, 10-26.

[15] Souzy, R., Ameduri, B., Boutevin, B., Gebel, G. and Capron, P. (2005) Functional Fluoropolymers for Fuel Cell Membranes. Solid State Ionics, 176, 2839-2848.

[16] Yamaki, T. (2010) Quantum-Beam Technology: A Versatile Tool for Developing Polymer Electrolyte Fuel-Cell Membranes. Journal of Power Sources, 195, 5848-5855.

[17] Gode, P., Ihonen, J., Strandroth, A., Ericson, H., Lindbergh, G., Paronen, M., Sundholm, F., Sundholm, G. and Walsby, N. (2003) Membrane Durability in a PEM Fuel Cell Studied using PVDF Based Radiation Grafted Membranes. Fuel Cells, 3, 21-27. https://doi.org/10.1002/fuce.200320239

[18] Horsfall, J.A. and Lovell, K.V. (2002) Comparison of Fuel Cell Performance of Selected Fluoropolymer and Hydrocarbon Based Grafted Copolymers Incorporating 
Acrylic Acid and Styrene Sulfonic Acid. Polymer Advance and Technology, 13, 381-390. https://doi.org/10.1002/pat.202

[19] DeLuca, N.W. and Elabd, Y.A. (2006) Polymer Electrolyte Membranes for the Direct Methanol Fuel Cell: A Review. Journal of Polymer Science Polymer Physics, 44, 2201-2225. https://doi.org/10.1002/polb.20861

[20] Ben-youcef, H., Gubler, L., Schmitz, A.F. and Scherer, G.G. (2011) Improvement of Homogeneity and Interfacial Properties of Radiation Grafted Membranes for Fuel Cells using Diisopropenyl Benzene Crosslinker. Journal of Membrane Science, 381, 102-109.

[21] Gubler, L. and Scherer, G.G. (2010) Trends for Fuel Cell Membrane Development. Desalination, 250, 1034-1037.

[22] Balog, S., Gasser, U., Mortensen, K., Ben-youcef, H., Gubler, L. and Scherer, G.G. (2012) Structure of the Ion-Rich Phase in DVB Cross-Linked Graft-Copolymer Proton-Exchange Membranes. Polymer, 53, 175-182.

[23] Fei, G., Kang, S.A., Ko, B.S., Lee, Y.S., Nho, Y.C. and Shin, J. (2010) Influence of the Radiation Grafting Conditions on the Cross-Sectional Distribution of Poly (vinylbenzyl Chloride) Grafted Polymer onto Poly (tetrafluoroethylene-co-hexafluoropropylene) Films. Journal of Applied Polymer Science, 117, 2380-2385.

https://doi.org/10.1002/app.32078

[24] Sung, A.K., Junhwa, S., Geng, F., Beom-Seok, K., Chong-Yeal, K. and Nho, Y.C. (2010) Radiolytic Preparation of Poly(styrene sulfonic acid)-Grafted Poly (tetrafluoroethylene-co-perfluorovinyl vinyl ether) Membranes with Highly Cross-Linked Networks. Nuclear Instruments and Methods in Physics Research B, 268, 3458-3463.

[25] Lappan, U., Geissler, U., Gohs, U. and Uhlmann, S. (2010) Grafting of Styrene into Pre-Irradiated Fluoropolymer Films: Influence of Base Material and Irradiation Temperature. Radiation Physics and Chemistry, 79, 1067-1072.

[26] Dargaville, T.R., George, G.A., Hill, D.J.T. and Whittaker, A.K. (2003) High Energy Radiation Grafting of Fluoropolymers. Progress in Polymer Science, 28, 1355-1376.

[27] Qiu, J., Ni, J., Zhai, M., Peng, J., Zhou, H., Li, J. and Wei, G. (2007) Radiation Grafting of Styrene and Maleic Anhydride onto PTFE Membranes and Sequent Sulfonation for Applications of Vanadium Redox Battery. Radiation Physics and Chemistry, 76, 1703-1707.

[28] Bhattacharya, A. and Misra, B.N. (2004) Grafting: A Versatile Means to Modify Polymers Techniques, Factors and Applications. Progress in Polymer Science, 29, 767-814.

[29] Dworjanyn, P.A., Garnett, J.L., Khan, M.A., Maojun, X., Meng-Ping, Q. and Nho, Y.C. (1993) Novel Additives for Accelerating Radiation Grafting and Curing Reactions. Radiation Physics and Chemistry, 42, 31-40.

[30] Kang, S., Shin, J., Fei, G., Ko, B.S., Kim, C.Y. and Nho, Y.C. (2010) Radiolytic Preparation of Poly(styrene sulfonic acid) Grafted Poly (tetrafluoroethylene-co-perfluorovinyl vinyl ether) Membranes with Highly Cross-Linked Networks. Nuclear Instruments and Methods. Physics Research B, 268, 3458-3463.

[31] Chen, J., Asano, M., Yamaki, T. and Yoshida, M. (2006) Effect of Crosslinkers on the Preparation and Properties of ETFE-Based Radiation-Grafted Polymer Electrolyte Membranes. Journal of Applied Polymer Science, 100, 4565-4574. https://doi.org/10.1002/app.22567

[32] Gupta, B., Büchi, F.N., Scherer, G.G. and Chapir, A. (1996) Crosslinked Ion Ex- 
change Membranes by Radiation Grafting of Styrene/Divinylbenzene into FEP Films. Journal Membrane Science, 118, 231-238.

[33] Ang, C.H., Garnett, J.L., Levot, R. and Long, M.A. (1982) Polyfunctional Monomers as Additives for Enhancing the Radiation Copolymerization of Styrene with Polyethylene, Polypropylene, and PVC. Journal of Applied Polymer Science, 27, 4893-4895. https://doi.org/10.1002/app.1982.070271235

[34] Nho, Y.C., Chen, J. and Jin, J.H. (1999) Grafting Polymerization of Styrene onto Preirradiated Polypropylene Fabric. Radiation Physics and Chemistry, 54, 317-322.

[35] Zhao, C., Shi, S., Mir, D., Hurst, D., Li, R., Xiao, X., Lillig, J. and Czarnik, A.W. (1999) Polystyrene Grafted Fluoropolymer Microtubes: New Supports for Solid-Phase Organic Synthesis with Useful Performance at High Temperature. Journal of Combinatorial Chemistry, 1, 91-95. https://doi.org/10.1021/cc980011c

[36] Garnett, J.L. and Yen, N.T. (1974) Effect of Acid on the Radiation-Induced Grafting of Monomers to Polyolefins. Polymer Letters, 12, 225-229. https://doi.org/10.1002/pol.1974.130120409

[37] Garnett, J.L., Jankiewicz, S.V. and Sangster, D.F. (1990) Mechanistic Aspects of the Acid and Salt Effect in Radiation Grafting. Radiation Physics and Chemistry, 36, 571-579.

[38] United States Patent (2001) US 6,306,975 B1.

[39] Nasef, M.M. (2001) Effect of Solvents on Radiation-Induced Grafting of Styrene onto Fluorinated Polymer Films. Polymer International, 50, 338-346.

https://doi.org/10.1002/pi.634

[40] Gürsel, S.A., Gubler, L., Gupta, B. and Scherer, G.G. (2008) Radiation Grafted Membranes. Advance in Polymer Science, 215, 157-217.

[41] Gubler, L., Gürsel, S.A. and Scherer, G.G. (2005) Radiation Grafted Membranes for Polymer Electrolyte. Fuel Cell, 5, 318-335. https://doi.org/10.1002/fuce.200400078

[42] Gubler, L., Kuhn, H., Schmidt, T.J., Scherer, G.G., Brack, H.P. and Simbeck, K. (2004) Performance and Durability of Membrane Electrode Assemblies Based on Radiation-Grafted FEP-g-Polystyrene Membranes. Fuel Cells, 4, 196-207. https://doi.org/10.1002/fuce.200400019

[43] Ben-youcef, H., Gürsel, A.S., Wokaun, A. and Scherer, G.G. (2008) The Influence of Crosslinker on the Properties of Radiation-Grafted Films and Membranes Based on ETFE. Journal of Membrane Science, 311, 208-215.

[44] Ben-youcef, H., Gubler, L., Yamaki, T., Sawada, S., Gürsel, A.S., Wokaun, A. and Scherer, G.G. (2009) Cross-Linker Effect in ETFE-Based Radiation-Grafted Proton-Conducting Membranes. Journal of Electrochemical Society, 156, B532-B539. https://doi.org/10.1149/1.3082109

[45] Gubler, L., Prost, N., Gürsel, S.A. and Scherer, G.G. (2005) Proton Exchange Membranes Prepared by Radiation Grafting of Styrene/Divinyl Benzene onto Poly(ethylene-alt-tetrafluoroethylene) for Low Temperature Fuel Cells. Solid State Ionics, 176, 2849-2860.

[46] Nasef, M.M. and Hegazy, E.S.A. (2004) Preparation and Applications of Ion Exchange Membranes by Radiation-Induced Graft Copolymerization of Polar Monomers onto Non-Polar Films. Progress in Polymer Science, 29, 499-561.

[47] Gubler, L., Ben-youcef, H., Gürsel, AS., Wokaun, A. and Scherer, G.G. (2008) Cross-Linker Effect in ETFE-Based Radiation-Grafted Proton-Conducting Membranes I. Properties and Fuel Cell Performance Characteristics. Electrochemical Society, 155, B921-B928. https://doi.org/10.1149/1.2951919 
[48] Buzanowski, W.C., Graham, J.D., Priddy, D.B. and Shero, E. (1992) Spontaneous Polymerization of Styrene in the Presence of Acid: Further Confirmation of the Mayo Mechanism. Polymer, 33, 3055-3059.

[49] Woods, R.J. and Pikaev, A.K. (1994) Applied Radiation Chemistry: Radiation Processing. Wiley, New York.

[50] Brack, H.P., Büchi, F.N., Huslage, J., Rota, M., Scherer, G.G., Pinnau, I., Freeman B.D., (Eds.) (2000) Membrane Formation and Modification. Applications Based on Poly(ethylene-alt-tetrafluoroethylene). ACS Symposium Series, American. Chemical Society, 744, 174-188.

[51] Mark, J.E. (1996) Physical Properties of Polymers Handbook. AIP Press, Woodbury, New York.

[52] Brandrup, J. and Immergut, E.H. (1989) Polymer Handbook. 3d Edition, Wiley-Interscience, New York. 